\title{
Is Morphometry an Indicator of the Number of Sexy Syllables in the Song of Yellow-Fronted Canary (Serinus mozambicus)?
}

\author{
Adoté Hervé Gildas Akueson ${ }^{1,2}$, Ayédèguè Eustache Alaye ${ }^{2}$ and Arcadius Yves Justin Akossou 1,2,*(D) \\ 1 Department of Natural Resources Management, Doctoral School of Agricultural and Water Sciences, \\ University of Parakou, Parakou BP 123, Benin; secretariat@fa-up.bj \\ 2 Unit of Applied Statistics and Informatics (USIA), Laboratory of Studies and Research in Forestry (LERF), \\ University of Parakou, Parakou BP 123, Benin; alaye3195eustache@gmail.com \\ * Correspondence: arcadius.akossou@fa-up.bj; Tel.: +229-97725883
}

check for updates

Citation: Akueson, A.H.G.; Alaye, A.E.; Akossou, A.Y.J. Is Morphometry an Indicator of the Number of Sexy Syllables in the Song of YellowFronted Canary (Serinus mozambicus)? Diversity 2021, 13, 542. https:// doi.org/10.3390/d13110542

Academic Editor: Luc Legal

Received: 6 September 2021

Accepted: 26 October 2021

Published: 28 October 2021

Publisher's Note: MDPI stays neutral with regard to jurisdictional claims in published maps and institutional affiliations.

Copyright: (c) 2021 by the authors. Licensee MDPI, Basel, Switzerland. This article is an open access article distributed under the terms and conditions of the Creative Commons Attribution (CC BY) license (https:/ / creativecommons.org/licenses/by/ $4.0 /)$.

\begin{abstract}
Birds use song for several goals as defending territory, alerting a partner to the presence of a predator, or wooing a female for breeding. This study aims to identify the morphometric parameters which determine the variability of the number of syllables in the "sexy" songs of yellow-fronted canary. For this purpose, sixteen morphometric parameters were measured among 170 yellow-fronted canaries captured, in four agroecological zones in North Benin. The results showed that the morphometry of yellow-fronted canary varies according to its habitat and the type of song. The categorization of the sample studied allowed to retain two groups which differ in the importance of body characters and the number of sexy syllables issued when singing. Yellow-fronted canaries from the Sudanese climate zone not only have superior morphometric characters compared to other zones, but also have a song composed of several different sexy syllables. A binary logistic regression model with selection of variables revealed that the index of beak shape, abdomen length, and tail length are the determining characteristics of the number of sexy syllables. These results are needed for future breeding and conservation studies of the species.
\end{abstract}

Keywords: yellow-fronted canary; morphometry; song; agroecological zone; Benin

\section{Introduction}

Birds have always had a privileged place with man, being appointed as signs of elevation and connected with the divine according to Platon [1]. They are real initiation tools for learning about wildlife [2] and good environmental indicators for ecological diagnostics [3]. Bird song is one of the most widely used means of communication in both oscine and suboscine birds [4]. Songbirds use acoustic signals to elicit courtship and defend territories from rival conspecifics [5]. In addition, in many species of songbirds or Passeriformes, including yellow-fronted canary, the song behavior is produced both to defend either a territory and to attract a partner. The type of song in canaries is acquired through a training process of singing until their productions match the pattern memorized earlier [1]. Markowitz et al. [6] showed in canaries (Serinus canaria), a closely related species to yellow-fronted canary, that their song is subdivided into phrases and syllables. The syllable is the basic unit of song [7]. It is a note or a set of notes uttered to attract a female, which explains its "sexy" song name. According to Aubin et al. [8] among the birds likely to learn to sing, there are two categories:- "age-limited learners", who learn to build their song during a limited period of their life, corresponding to the first weeks following their emergence, and - "open-ended learners", who are able to modify their singing and acquire new notes and syllables throughout their lives. The song of the yellow-fronted canary is made up of notes, which together form syllables. These latter form phrases. The arrangement of syllables follows rules, and behaviorally birds can discriminate songs based on this arrangement. The songs of the different species of songbird are differentiated by the spectro-temporal characteristics of the notes, but also by their organization [9]. Sexy 
syllables are bipartite syllables linked to a "two-voice" phenomenon composing the "sexy" trills of male canaries [10]. In the organization of songbird, we can distinguish a simple syllable, made up of a single note and a complex syllable, which is the repetition of two or more different notes. The phrase "sexy" is a repetition of syllables complexes covering a large frequency span [8].

These syllables produce sexual responses in females [11]. Kreutzer et al. [12] explained that the songs of males reared in isolation may contain elements that produce a large number of sexual responses in females. Amy et al. [13] and Monbureau et al. [14] have shown how "sexy" syllables are at the basis of the diversity of sexual selection. For Pasteau et al. [15], female canaries like songs containing complex syllables, composed of more than one note, to those containing only simple syllables. The intensity of the vocal productions, the quantity of songs produced, the size of the repertoire, but also the type of vocalizations emitted are all indicators of the quality of the male. The number of syllables and the intensity of the song of the males is, moreover, a factor for obtaining a better hatching rate of the females, which is what Garcia-Fernandez [16] explained by stipulating that the females use the "covering songs" to choose their partner. They will invest more resources in their eggs if they hear an overlapping song rather than a "covered song". Females paired with their favorite males invest energy in yolk deposition. Bortolotti et al. [17] reported that the genetic quality of the male and the environment in which he has developed as well as his current physical condition impact syllables production, body size, color, and vocalizations, and can be good indicators of individual quality; therefore, it is used as such when choosing a partner. Several studies, going in the same direction, in a wide range of oscine species [18-22], have been reported that developmental stress, such as physical development, hormone level, and early rearing condition, affects various song traits. Podos [23], based on his studies of Darwin's finches, suggested that in some cases, it is adaptation that produces the divergence of sexual signals, thus leading to pre-productive isolation. The size and structure of the various organs of the vocal tract will constrain the type of sound that birds can emit [24]. In particular, Podos [23] and Podos and Nowicki [25] have shown that the size of the beak influences the sound signals that an individual emits.

Therefore, songbird, as a sexually selected multidimensional signal, can reveal singer information to some extent [4]. Thus, what are the factors that determine this complexity of patterns composed of more than one sexy syllable or note?

According to Ota and Soma [26], songbird reflects life history, and age is a crucial limiting or mediating factor for it. In fact, according to these authors, early developmental stress affects neural development of song control systems, and leaves irreversible adverse effects on song phenotypes. It is also well known that advertising songs can indicate body size $[27,28]$. In the literature, the results of the link between song traits and morphological characteristics are divergent. Some studies have shown that all song characteristics reveal signal quality through traits, such as repertoire size [4,18,19,26,29-32], song timing [33], song amplitude [34,35], song frequency, song bandwidth, or song rate [36-42]. Other studies, on the other hand, have shown that song bandwidths, song rate, average frequency, song amplitude, and repertoire size of the total song showed no relationship to body size $[34,43,44]$. Thus, in these studies, song characteristics failed to predict the body size of songbirds.

Therefore, females are unlikely to assess the size of male birds solely from individual parts of the song, but rather use the total song in their assessment of males [4]. Although the literature has made reference to the link between singing traits and morphology, perhaps some fine-scaled variation in sound production can reflect body size [4], notably the number of sexy syllables in a song.

This research, therefore, intends to resolve this problem in the yellow-fronted canary, which is among the passerines, the most widespread species as a companion species in Benin. It is widely kept as a pet and is very expensive, given its importance, especially in terms of its virtues and its use in betting games based on the number of sexy syllables in 
his song. Therefore, this study aims to determine the morphometric and environmental factors enabling to differentiate yellow-fronted canaries with regard to the number of sexy syllables contained in their song.

\section{Materials and Methods}

\subsection{Study Zone}

Data collection was carried out in ten localities belonging to four agroecological zones (ZAE): Kandi $\left(11^{\circ} 07^{\prime} 43^{\prime \prime} \mathrm{N}, 2^{\circ} 56^{\prime} 13^{\prime \prime} \mathrm{E}\right)$, Bembèrèkè $\left(10^{\circ} 13^{\prime} 30^{\prime \prime} \mathrm{N}, 2^{\circ} 40^{\prime} 05^{\prime \prime} \mathrm{E}\right)$, Bouca $\left(10^{\circ} 12^{\prime} 47^{\prime \prime} \mathrm{N}, 3^{\circ} 08^{\prime} 20^{\prime \prime} \mathrm{E}\right)$, NDali $\left(9^{\circ} 51^{\prime} 39^{\prime \prime} \mathrm{N}, 2^{\circ} 43^{\prime} 05^{\prime \prime} \mathrm{E}\right)$, Nikki $\left(9^{\circ} 56^{\prime} 00^{\prime \prime} \mathrm{N}, 3^{\circ} 12^{\prime} 30^{\prime \prime} \mathrm{E}\right)$, Tamarou $\left(9^{\circ} 44^{\prime} 19^{\prime \prime} \mathrm{N}, 2^{\circ} 41^{\prime} 26^{\prime \prime} \mathrm{E}\right)$, Afon $\left(9^{\circ} 44^{\prime} 56^{\prime \prime} \mathrm{N}, 2^{\circ} 5^{\prime} 19^{\prime \prime} \mathrm{E}\right)$, Djougou $\left(9^{\circ} 42^{\prime} 00^{\prime \prime} \mathrm{N}\right.$, $\left.1^{\circ} 40^{\prime} 00^{\prime \prime} \mathrm{E}\right)$, Parakou $\left(9^{\circ} 42^{\prime} 00^{\prime \prime} \mathrm{N}, 1^{\circ} 40^{\prime} 00^{\prime \prime} \mathrm{E}\right)$, and Tchaourou $\left(8^{\circ} 53^{\prime} 00^{\prime \prime} \mathrm{N}, 2^{\circ} 36^{\prime} 00^{\prime \prime} \mathrm{E}\right)$. These localities are distributed in four agroecological zones (Figure 1). The distance between two localities is presented in Table 1.

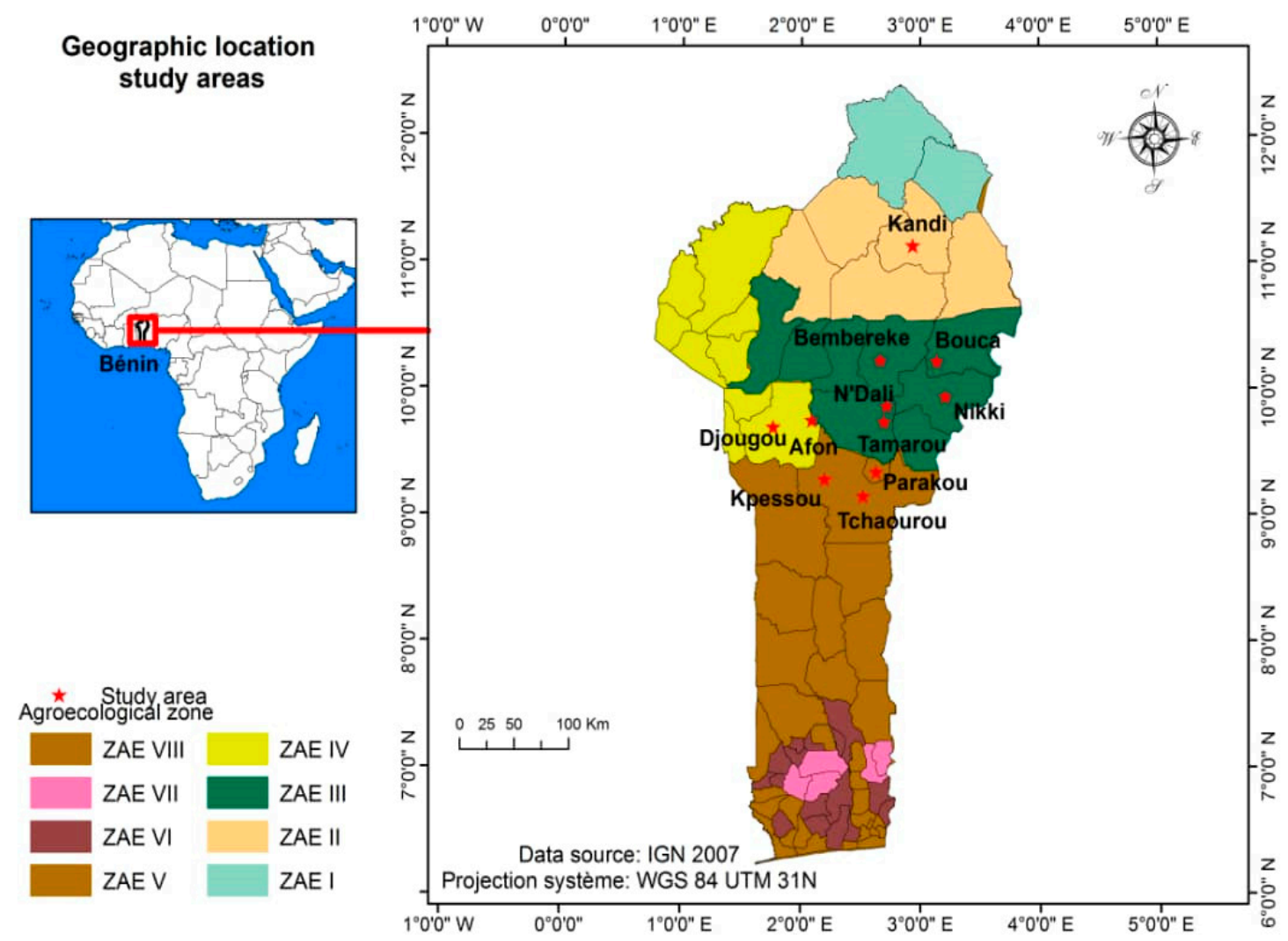

Figure 1. Map of study localities.

Table 1. Distance between the different study localities.

\begin{tabular}{|c|c|c|c|c|c|c|c|c|c|}
\hline & Afon & Bembèrèkè & Bouca & Djougou & Kandi & $N^{\prime}$ dali & Nikki & Tamarou & Tchaourou \\
\hline Bembèrèkè & 172 & - & & & & & & & \\
\hline Bouca & 171 & 155 & - & & & & & & \\
\hline Djougou & 49 & 173 & 232 & - & & & & & \\
\hline Kandi & 283 & 207 & 357 & 375 & - & & & & \\
\hline $\mathrm{N}^{\prime}$ dali & 124 & 48 & 107 & 125 & 159 & - & & & \\
\hline Nikki & 179 & 108 & 47 & 180 & 214 & 55 & - & & \\
\hline Tamarou & 139 & 63 & 122 & 140 & 174 & 15 & 70 & - & \\
\hline Tchaourou & 236 & 163 & 227 & 189 & 276 & 105 & 185 & 100 & - \\
\hline Parakou & 179 & 103 & 162 & 135 & 216 & 55 & 115 & 40 & 60 \\
\hline
\end{tabular}

In ZAE II (Kandi), the study was carried out in tree and shrub savannah with an agricultural influence with very diverse vegetation. This vegetation consists of the 
plants of Parkia biglobosa, Vittelaria Paradoxa, and Western Anarcadium and food crops such as millet, maize, and other grasses which are part of the food base of yellow-fronted canaries. This makes this area a diversified supply area for yellow-fronted canaries.

ZAE III (Béméberéké, N'dali, Bouka, Tamarou, and Nikki) consists of wooded savannah, with woodland in places. Fields of millet and maize are sparsely found.

ZAE IV (Djougou and Afon) is a fairly dense wooded savannah area where the dominant species are Isoberlinia doka, Burkea africana, Monotes kerstingii, Anogeissus leiocarpus, and Kaya senegalensis.

The ZAE V (Parakou and Tchaourou) constitutes a zone of natural vegetation located by open forests to which are added gallery forests, savannas, and fallows.

From a climatic point of view, the Kandi area has a Sudanese-type climate with a dry season extending from November to April and a rainy season from May to October, while Bembèrèkè has a South Sudanese continental type climate which gradually changes to the North Sudanese type in the far north. This climate is characterized by the succession in the year, of a single dry season from November to March and a rainy season from May to October with maximums in July and August depending on the year. The Bouca area has a savannah climate with dry rainy season according to the Köppen-Geiger classification. In the dry season, there is much more rainfall in Bouca and in Ndali than in the rainy season. The average temperature in Ndali is $26.8^{\circ} \mathrm{C}$, and the precipitation averages is $1023.6 \mathrm{~mm}$. In Nikki, the rainy season is oppressive and overcast, the dry season is partly cloudy, and the climate is very hot all year round. Djougou area is characterized by a savannah climate and a dry rainy season. As for Parakou, the dry season is wet and partly cloudy and the climate is very hot throughout the year. During the year, the temperature generally ranges from $20^{\circ} \mathrm{C}$ to $36{ }^{\circ} \mathrm{C}$ and is rarely below $17^{\circ} \mathrm{C}$ or above $39^{\circ} \mathrm{C}$. In Tchaourou, the dry season is wet and partly cloudy and the climate is very hot throughout the year.

Within each of the ten localities selected for the study, data collection was carried out at several sites. The main criterion for choosing these sites is based on the presence of a stream, which allows the animal to be observed and facilitates its capture.

\subsection{Data Collection}

A total of 170 yellow-fronted canaries distributed over the ten sites were captured around each water point using the trap cage, between 8 am and $12 \mathrm{pm}$ and between $3 \mathrm{pm}$ and $6 \mathrm{pm}$. The number of yellow-fronted canaries captured per site was calculated according to the density of the bird population at the site (determined by the absolute method). Each bird has been badged with an identification number that includes the name of the site and the order of capture number. Morphometric parameters, such as head and abdomen widths, beak height, total length, as well as the lengths of the: head, beak, chest, abdomen, thigh, tarsus, tail, wing, and wings in flight, were measured using a caliper and a tape measure. The weight of each bird was collected using a digital scale accurate to the gram. The various individual body measurements (Figure 2) were carried out according to the definitions presented in Table 2.

The relative tarsus length (LongRT) and the index of beak shape (IFB) (Equation (1)) were calculated based on measurements of tarsal length and wing length on the one hand, and measurements of the beak (beak height and beak length) on the other hand [45]:

$$
\text { LongRT }=\frac{\text { LongTa }}{\text { LongAi }} \text { and IFB }=\frac{\text { LongBe }}{\text { HautBe }}
$$

To determine the number of sexy syllables contained in the song of each bird, every bird was tracked from capture in order to identify each bird's song repertoire. This monitoring was carried out for a whole year and during two sequences of the molting processing in order to ensure the stability of the syllables, the crystallization of the song, a better vocal performance, and the maturity of the song of the bird [46]. 


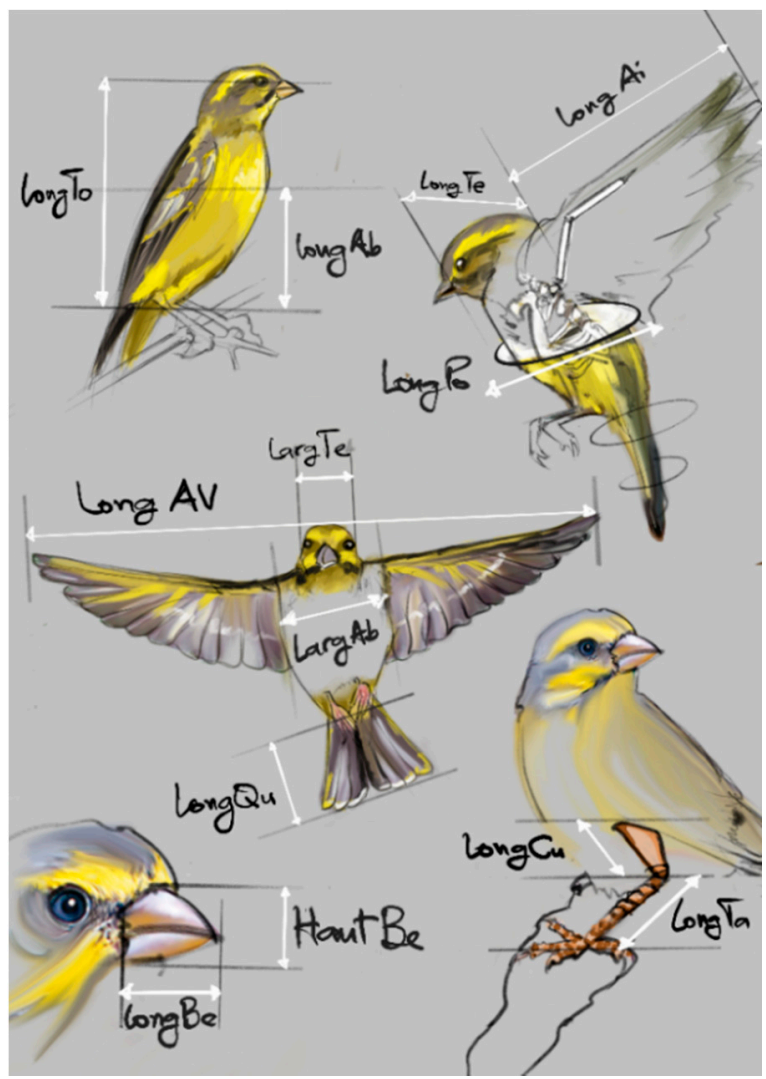

Figure 2. Different body measurements of the bird.

Table 2. Acronyms and definitions of the measured morphometric parameters.

\begin{tabular}{ccl}
\hline Parameter & Acronym & Definition \\
\hline Total or body length & LongTo & Distance between the tip of the upper mandible and that of the tail (without feather) \\
\hline Chest length or chest girth & LongPo & $\begin{array}{l}\text { Circumference of the chest taken below the wings and at the level of the protruding } \\
\text { region of the keel }\end{array}$ \\
\hline Wing length & LongAi & $\begin{array}{l}\text { Length of the wing extended from the junction of the humerus at the spine to the tip of } \\
\text { the wing (without feather) }\end{array}$ \\
\hline Spout length & LongBe & Distance between the tip of the upper mandible and the commissure of both mandibles \\
\hline Tarsal length & LongTa & Distance between the calcaneus and the ankle (part of the bird's leg located after the thigh) \\
\hline Head length & LongTe & Length between nostrils and neck \\
\hline Tail length & LargTe & Distance between the two eyebrows \\
\hline Wing length in flight & LongAV & $\begin{array}{l}\text { Length of central rectrix } \\
\text { apart to mimic bird flight }\end{array}$ \\
\hline Abdomen length & LongAb & Distance between wishbone and cloaca \\
\hline Abdomen width & LargAb & Rib cage width \\
\hline Thigh length & LongCu & Upper part of the bird's leg \\
\hline Spout height & HautBe & $\begin{array}{l}\text { Distance between the lower part of the mandible and the upper part of the mandible (at } \\
\text { the base of the beak where plumage begins) }\end{array}$ \\
\hline Spout length & LongBe & Distance from the tip of the beak to the base of the skull \\
\hline
\end{tabular}


Sexy syllables were identified after the songs were recorded using the method of Amy et al. [13]. The procedure consisted of putting the females temporarily in a cage during the period they are accepting the males (mating and egg laying period), then subjecting them to listening the songs and analyzing their behavior. The mating and egg laying period, which runs from July to November, is the ideal time to better appreciate the effect of sexy syllables on the behavior of females. Calling postures were used to detect female preferences. When the female is complete, she arches her back and lifts her tail, head and neck. When she lifts the feathers of her cloaca which vibrate, then we identify the responsible syllable, by locating the range of song on the spectrogram. Then, this corresponds to a "sexy" syllable. Syllables were visually examined on spectrograms (FFT 1024, window: Hamming, overlap 87.5) and waveforms to identify amplitude frequency modulations over time. Figure 3 showed a song consisting of a single sexy syllable repeated over time. On the other hand, Figure 4 showed a song composed of three different sexy syllables repeated over time.

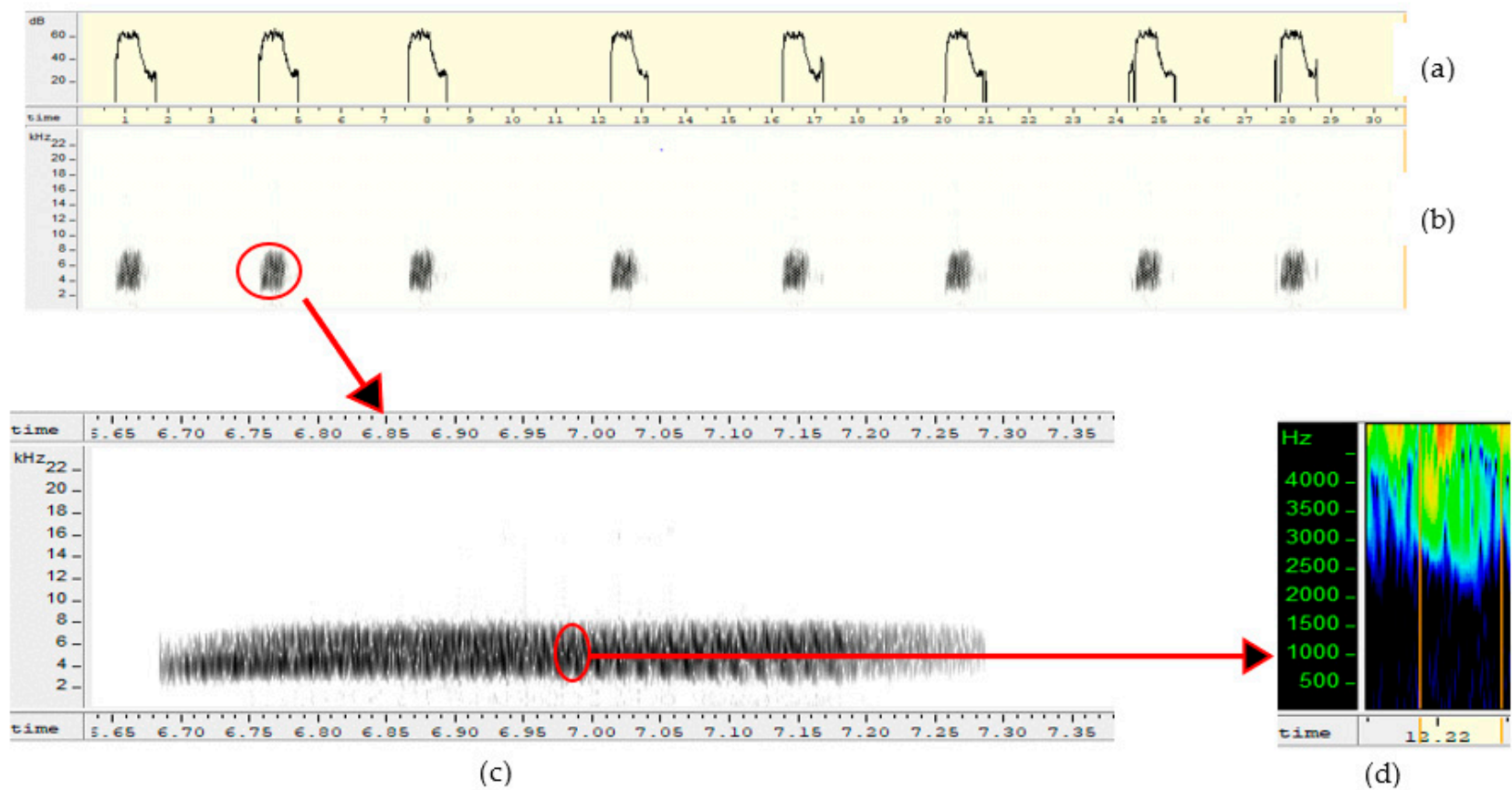

Figure 3. Song showing identical sexy syllable repeated in song: $(\mathbf{a}, \mathbf{b})=$ representation of a song composed of an identical sexy syllable repeated over time (frequency as a function of time and decibels as a function of time), (c) = enlarged spectrogram of sexy syllable showing the evolution of song frequency over time, $(\mathbf{d})=$ notes.

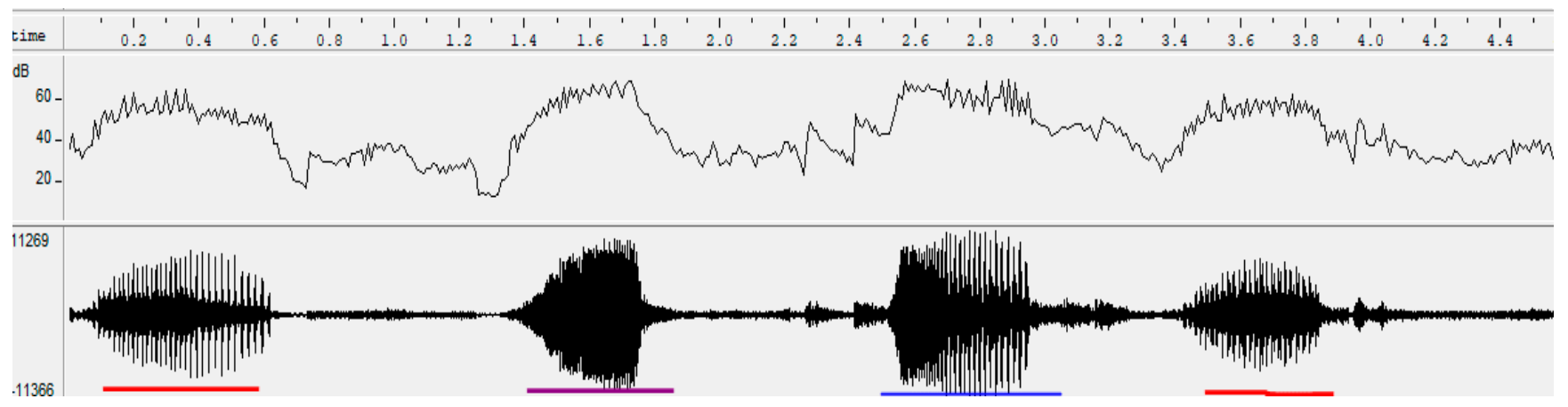

Figure 4. Song made up of three different sexy syllables. The syllables underline with the same colors are identical.

All recordings were made using a Marantz Pro portable recorder, PMD661MK3. The songs were analyzed by the wavesurfer 1.8.8 software (developed at the Centre for Speech 
Technology at KTH in Stockholm, Sweden, and is provided as open source, under a BSD style license).

\subsection{Data Analysis}

The types of song were previously classified into two categories: Type I songs consisting of a single sexy syllable on the one hand and Type II songs consisting of at least two, three, or four sexy syllables on the other hand. Data analysis was performed using $\mathrm{R}$ software, version 4.0.4 (open source created by Ross Ihaka and Robert Gentleman from Auckland, New Zealand) [47].

First, a summary of the data was carried out using descriptive statistics tools (mean and coefficient of variation). Then, the relationships between the pairs of morphometric characters were evaluated by calculating the Pearson correlation coefficients, and their significance was tested at the $5 \%$ level.

The effects of the agroecological zone on the one hand and the effect of song type on the other hand on each characteristic were examined separately by using an analysis of variance (ANOVA). The analysis model is a fixed model with one classification criterion. The factor is firstly the agroecological zone and secondly the type of song. For each model, the response variable is each of the morphometric characteristics. When a difference occurs, the structuring of the means was carried out using the method of Newman and Keuls.

In order to assess the interrelationships between the variables (morphological characteristics, agroecological zones and number of songs) taken simultaneously, a factor analysis on mixed data (FAMD) followed by a numerical classification was carried out.

Finally, the procedure generalized linear models (GLM) with a Binomial distribution and the logit as a link function was used to perform a binary logistic regression model (logit model). A variable selection was also made in order to identify the morphometric parameters having a significant effect on the number of sexy syllables (one or more) in a song of the yellow-fronted canaries studied. Binary logistic regression was chosen instead of polytonic regression, given the small numbers of birds observed for the three and four syllable modalities in a song. Thus, the first class consists of data relating to a sexy syllable in a song and the second class relates to a grouping of data for which the number of sexy syllables in a song is greater than or equal to two. The selection methods tested were as follows: backward/forward, forward/backward, forward, and backward, with as selection criteria the Bayesian information criterion or BIC [48] and the Akaike or AIC information criterion [49]. The goodness of fit of each model was assessed by residual deviance and AIC.

Binary logistic regression is a technique used to analyze the relationship between a dependent variable $y$, qualitative, nominal with two modalities (coded $y=0$ and $y=1$ for example), and one or more explanatory variables $X_{i}(i=1, \ldots, \mathrm{k})$ quantitative and/or qualitative ordinal or nominal, assumed to be perfectly known. It is indeed a question of modeling the probability $\pi$ of emitting several sexy syllables in a song by an individual (bird) according to the morphometric parameters of this individual.

To achieve this, a transformation of the probabilities of success is carried out by link functions, denoted by $g$. Several link functions exist, but the most commonly used is the logit function (Equation (2)):

$$
g=\operatorname{logit}(\pi)=\ln [\pi /(1-\pi)]=x_{i}^{\prime} \beta(i=1, \cdots, n),
$$

where $x_{i}^{\prime}=\left(1, x_{i 1}, \cdots, x_{i k}\right)$ is the $1 \times(\mathrm{k}+1)$ vector corresponding to the $\mathrm{k}$ covariates associated with a single subject $i$ and $\beta=\left(\beta_{0}, \beta_{1}, \cdots, \beta_{k}\right)$ is the $(\mathrm{k}+1) \times 1$ vector of associated coefficients. $\beta$ is the vector containing the parameters to be estimated, most often by the maximum likelihood method. The inverse transformation makes it possible to find the estimated probabilities as a function of $x$ (Equation (3)):

$$
\pi=\exp (g) /[1+\exp (g)]
$$


For a given bird $i$ with the characteristics $x_{i}$, the ratio between the probability $\pi$ of having several sexy syllables in a song and the probability $(1-\pi)$ of having one sexy syllable in a song represents the odds, i.e., a report of odds. For example, if an individual has an odd of 2, it means that they are twice as likely to have multiple sexy syllables in their song. The ratio between the probability $\pi$ and the probability $(1-\pi)$ is equal to (Equation (4)):

$$
\pi /(1-\pi)=\exp (g)
$$

When the probability of success (having several sexy syllables in a song) is greater than the probability of failure (having one sexy syllable in a song), the odds are greater than unity. If the two probabilities are equal, the odds equal to 1 . Finally, if the probability of success is smaller than the probability of failure, the odds are less than unity.

\section{Results}

\subsection{Effect of Agroecological Zone}

Before examining the effect of the agroecological zone, a correlation study between the morphometric characters of yellow-fronted canaries (Figure 5) was performed to examine the relationship between the pairs of characters. These relationships have revealed, for the most part, that there is a correlation between the characters in each part of the bird's body. There are both positive and negative correlations. Thus, at the level of the beak, there is a strong correlation $(\mathrm{r}=-0.94)$ between the beak height and the index of the beak shape, and an average correlation $(r=0.54)$ between the beak length and the beak height on the one hand and the index of the beak shape and the beak height on the other hand $(r=-0.51)$. The head length and head width are very weakly correlated $(r=0.15)$. The characteristics abdomen length and chest length showed a weak correlation $(r=0.29)$ at the abdomen level. The tarsus length and the relative tarsus length were strongly correlated $(r=0.96)$, while the thigh length was weakly correlated with each of the two characters $(\mathrm{r}=-0.38$ and $\mathrm{r}=-0.35$, respectively). Although there was no correlation between the two wings characters, the wings length in flight did show correlations with other parts of the body. Thus, the wings length in flight is related by a relatively strong positive correlation with the total length $(r=0.6)$, the chest length $(0.52)$, the abdomen length $(r=0.50)$, and tail length $(r=0.52)$. The tail length is also related to several other parts of the body: beak height $(r=-0.62)$, beak length $(r=-0.60)$, index of the beak shape $(r=0.68)$, head width $(r=0.56)$, total length $(r=0.84)$, and chest length $(r=0.62)$. There were also relatively strong correlations between total length and weight $(r=0.53)$, breast length and total length (0.67), breast length and index of beak shape (0.67), breast length and beak height $(-0.62)$, total length and beak height $(-0.57)$, and total length and index of beak shape $(-0.51)$.

The evaluation of the effect of the agroecological zone (Table 3) showed that overall, the morphometric parameters vary according to the habitat of the species, except the abdomen width $(p>0.05)$. The birds of the Sudanese-type climate zone (zone II) are the most developed, that is to say, most of the time they have the highest morphometric parameters. These include weight $(17.38 \mathrm{~g})$, index of beak shape (6.08), head width $(1.76 \mathrm{~cm})$, overall length $(12.74 \mathrm{~cm})$, chest $(3.07 \mathrm{~cm})$, abdomen $(3.61 \mathrm{~cm})$, thigh $(2.32 \mathrm{~cm})$, tail $(4.90 \mathrm{~cm})$, and wings in flight $(21.08 \mathrm{~cm}$ ). The birds of zone IV (savannah climate and a dry winter) were characterized by long beak lengths $(1.12 \mathrm{~cm})$ and tarsus $(2.02 \mathrm{~cm})$ compared to those of other zones. As for the birds of zone V (Guinean savanna-type climate), they were distinguished by high values of beak height $(0.46 \mathrm{~cm})$ and wing length $(8.69 \mathrm{~cm})$. The variability of the measurements of each characteristic was low within an area and of the same order of magnitude from one area to another.

The number of sexy syllables in a song and the agroecological zone enabled to identify the existence of two large groups in the sample studied (Figure 6). The first group contains the birds of zones III, IV, and V having only one sexy syllable in their song. Birds in this group are generally small in size, having the lowest morphological parameters (weight $=16.72 \mathrm{~g}$, total length $=12.30 \mathrm{~cm}$, length of the head $=3.14 \mathrm{~cm}$, width of the head $=1.62 \mathrm{~cm}$, chest length $=2.69 \mathrm{~cm}$, abdomen length $=3.52 \mathrm{~cm}$, tail length $=4.42 \mathrm{~cm}$, 
wing length in flight $=19.60 \mathrm{~cm}$ ). Group 2, on the other hand, contains birds from zone II with several sexy syllables (two, three, or four) in their song. They are large birds with the highest morphological parameters (weight $=17.33 \mathrm{~g}$, total length $=12.74 \mathrm{~cm}$, head length $=3.17 \mathrm{~cm}$, head width $=1.77 \mathrm{~cm}$, chest length $=3.07 \mathrm{~cm}$, abdomen length $=3.63 \mathrm{~cm}$, tail length $=4.90 \mathrm{~cm}$, wing length in flight $=21.30 \mathrm{~cm}$ ). However, the birds of group 2 have shorter beaks (length $=0.83 \mathrm{~cm}$ and height $=0.32 \mathrm{~cm}$ ) than those of the first group (length $=1.04 \mathrm{~cm}$ and height $=0.43 \mathrm{~cm}$ ), and a wing length smaller $(8.57 \mathrm{~cm})$ than those of the first group $(8.61 \mathrm{~cm})$.

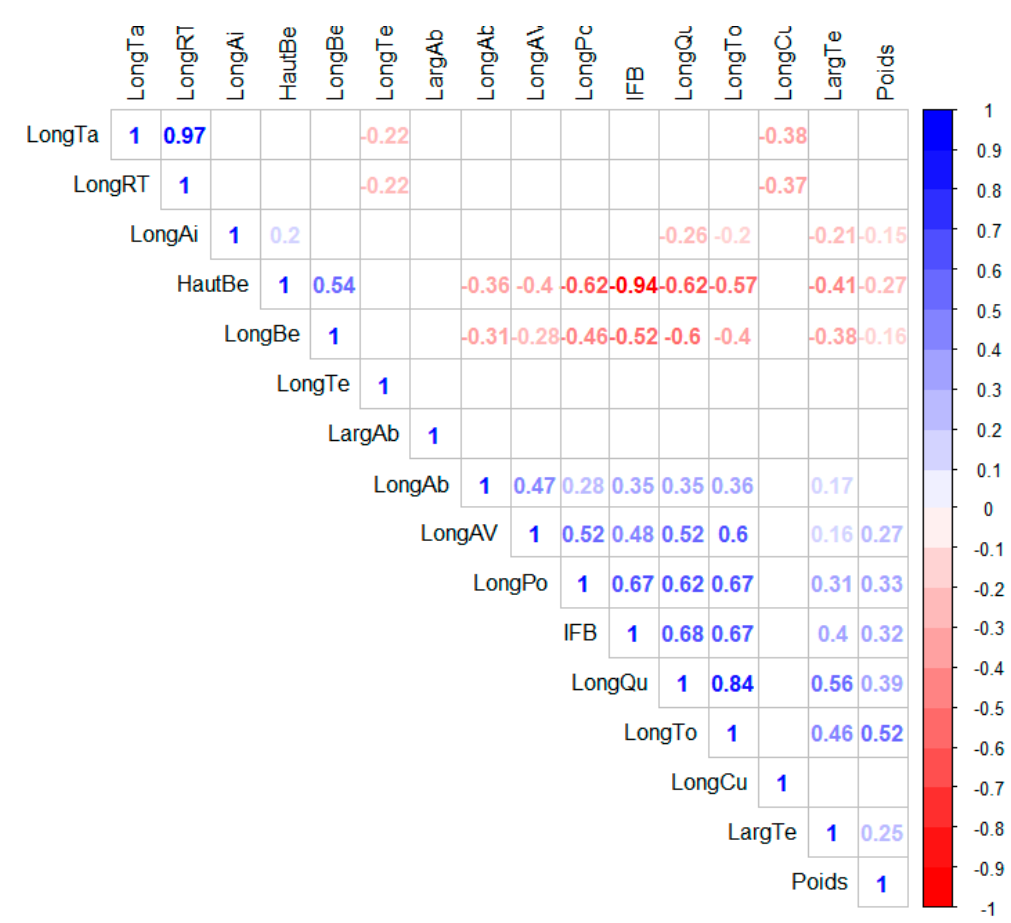

Figure 5. Graphical representation of the correlation matrix (correlogram): positive correlations are displayed in blue and negative correlations in red. The intensity of the color is proportional to the correlation coefficients. Correlations with a $p$-value $>0.05$ are considered insignificant. In this case, the boxes are replaced by white. To the right of the correlogram is the legend of the colors.

Table 3. Mean and coefficient of variation $(\mathrm{CV})$ of the morphometric characteristics of the yellow-fronted canary according to the AEZ.

\begin{tabular}{|c|c|c|c|c|c|}
\hline \multirow{2}{*}{ Variables } & \multirow{2}{*}{ Parameters } & \multicolumn{4}{|c|}{ Agroecological Zone } \\
\hline & & AEZ II $(n=48)$ & AEZ III $(n=66)$ & AEZ IV $(n=26)$ & $\operatorname{AEZ~V~}(n=30)$ \\
\hline \multirow[t]{2}{*}{ Weight } & Mean & $17.38 \mathrm{a}$ & $16.71 \mathrm{c}$ & $17.12 \mathrm{ab}$ & $16.72 \mathrm{c}$ \\
\hline & CV (\%) & 4.78 & 4.70 & 3.12 & 3.22 \\
\hline \multirow[t]{2}{*}{ LongTo } & Mean & $12.74 \mathrm{a}$ & $12.35 \mathrm{~cd}$ & $12.53 \mathrm{~b}$ & $12.28 \mathrm{~d}$ \\
\hline & CV (\%) & 0.60 & 2.47 & 1.21 & 1.37 \\
\hline \multirow[t]{2}{*}{ LongBe } & Mean & $0.83 \mathrm{c}$ & $0.96 \mathrm{~b}$ & $1.12 \mathrm{a}$ & $1.00 \mathrm{~b}$ \\
\hline & CV $(\%)$ & 9.24 & 14.11 & 8.94 & 11.55 \\
\hline \multirow[t]{2}{*}{ HautBe } & Mean & $0.32 \mathrm{c}$ & $0.39 \mathrm{~b}$ & $0.43 \mathrm{a}$ & $0.46 \mathrm{a}$ \\
\hline & CV (\%) & 13.42 & 15.53 & 10.95 & 10.85 \\
\hline \multirow[t]{2}{*}{ IFB } & Mean & $6.08 \mathrm{a}$ & $4.88 \mathrm{~b}$ & $4.71 \mathrm{~b}$ & $4.37 \mathrm{c}$ \\
\hline & $\mathrm{CV}(\%)$ & 11.00 & 18.21 & 10.99 & 11.64 \\
\hline \multirow[t]{2}{*}{ LongTe } & Mean & $3.17 \mathrm{a}$ & $3.17 \mathrm{a}$ & $3.10 \mathrm{~b}$ & $3.14 \mathrm{a}$ \\
\hline & CV (\%) & 2.34 & 2.47 & 2.45 & 2.68 \\
\hline
\end{tabular}


Table 3. Cont.

\begin{tabular}{|c|c|c|c|c|c|}
\hline \multirow{2}{*}{ Variables } & \multirow{2}{*}{ Parameters } & \multicolumn{4}{|c|}{ Agroecological Zone } \\
\hline & & AEZ II $(n=48)$ & AEZ III $(n=66)$ & AEZ IV $(n=26)$ & $\operatorname{AEZ~V~}(n=30)$ \\
\hline \multirow[t]{2}{*}{ LargTe } & Mean & $1.76 \mathrm{a}$ & $1.68 \mathrm{~b}$ & $1.62 \mathrm{~cd}$ & $1.60 \mathrm{~d}$ \\
\hline & $\mathrm{CV}(\%)$ & 7.31 & 6.34 & 6.69 & 5.48 \\
\hline \multirow[t]{2}{*}{ LongPo } & Mean & $3.07 \mathrm{a}$ & $2.78 \mathrm{~b}$ & $2.69 \mathrm{~b}$ & $2.76 \mathrm{~b}$ \\
\hline & $\mathrm{CV}(\%)$ & 3.68 & 9.88 & 4.42 & 6.37 \\
\hline \multirow[t]{2}{*}{ Long $\mathrm{Ab}$} & Mean & $3.61 \mathrm{a}$ & $3.56 \mathrm{~b}$ & $3.55 \mathrm{~b}$ & $3.52 \mathrm{~b}$ \\
\hline & CV $(\%)$ & 2.31 & 4.55 & 1.47 & 1.45 \\
\hline \multirow[t]{2}{*}{ LargAb } & Moy & $2.67 \mathrm{a}$ & $2.54 \mathrm{a}$ & $2.57 \mathrm{a}$ & $2.54 \mathrm{a}$ \\
\hline & $\mathrm{CV}(\%)$ & 22.70 & 1.33 & 7.03 & 6.81 \\
\hline \multirow[t]{2}{*}{ LongCu } & Moy & $2.32 \mathrm{a}$ & $2.30 \mathrm{ab}$ & $2.29 \mathrm{~b}$ & $2.31 \mathrm{ab}$ \\
\hline & $\mathrm{CV}(\%)$ & 2.22 & 0.92 & 1.40 & 2.49 \\
\hline \multirow[t]{2}{*}{ LongQu } & Moy & $4.90 \mathrm{a}$ & $4.53 \mathrm{~b}$ & $4.50 \mathrm{~b}$ & $4.44 \mathrm{~b}$ \\
\hline & $\mathrm{CV}(\%)$ & 1.86 & 5.95 & 5.03 & 2.94 \\
\hline \multirow[t]{2}{*}{ LongTa } & Moy & $1.90 \mathrm{c}$ & $1.84 \mathrm{~d}$ & $2.02 \mathrm{a}$ & $1.97 \mathrm{~b}$ \\
\hline & $\mathrm{CV}(\%)$ & 4.56 & 4.89 & 2.85 & 4.38 \\
\hline \multirow[t]{2}{*}{ LongRT } & Moy & $0.22 b c$ & $0.21 \mathrm{~d}$ & $0.24 \mathrm{a}$ & $0.23 \mathrm{~b}$ \\
\hline & CV (\%) & 4.99 & 4.49 & 3.08 & 4.28 \\
\hline \multirow[t]{2}{*}{ LongAi } & Moy & $8.54 \mathrm{~b}$ & $8.59 \mathrm{~b}$ & $8.57 \mathrm{~b}$ & $8.69 \mathrm{a}$ \\
\hline & CV $(\%)$ & 0.82 & 1.39 & 1.05 & 1.18 \\
\hline \multirow[t]{2}{*}{ LongAV } & Moy & $21.08 \mathrm{ab}$ & $19.61 \mathrm{c}$ & $20.87 \mathrm{~b}$ & $20.05 \mathrm{c}$ \\
\hline & CV (\%) & 4.58 & 8.73 & 8.50 & 6.28 \\
\hline
\end{tabular}

For a given variable, the mean values followed by the same letters on the same line are not significantly different at the $5 \%$ level.

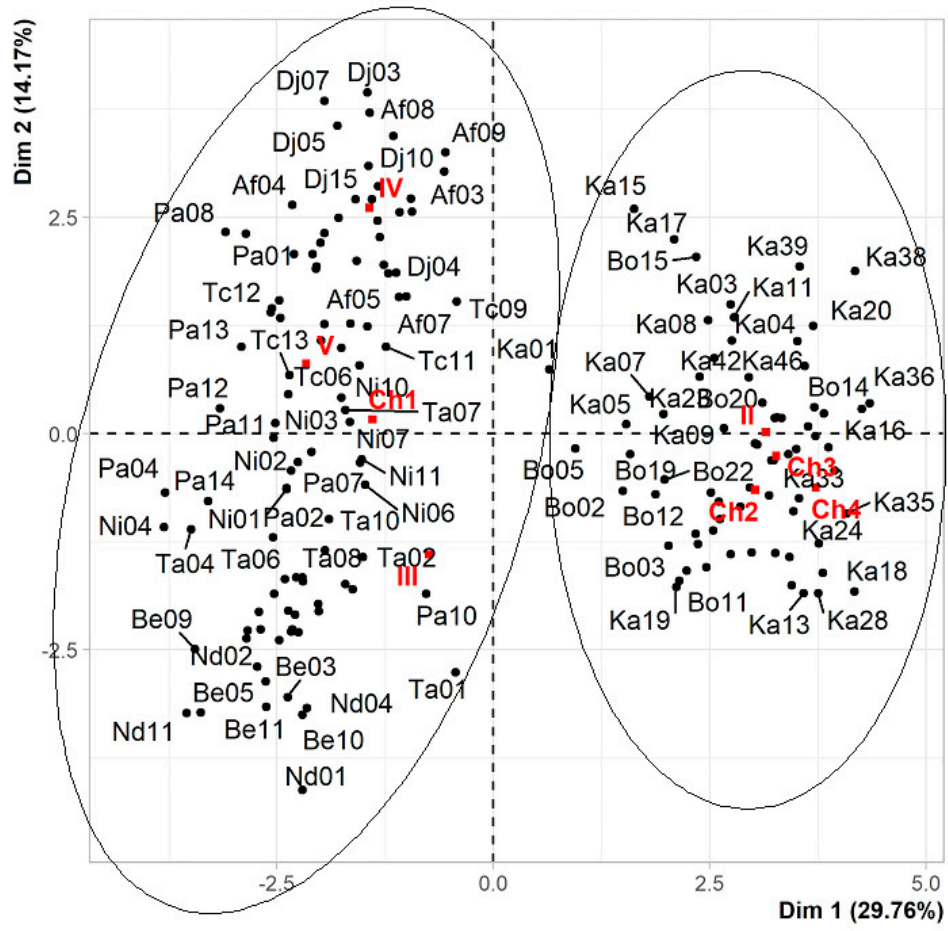

Figure 6. Distribution of yellow-fronted canaries in the first factorial map. (Ka $=\mathrm{Kandi}$, $\mathrm{Be}=$ Bembèrèkè, $\mathrm{Bo}=$ Bouca, $\mathrm{Nd}=$ NDali, $\mathrm{Ni}=$ Nikki, $\mathrm{Ta}=$ Tamarou $, \mathrm{Af}=\mathrm{Afon}, \mathrm{Dj}=$ Djougou, $\mathrm{Pa}=$ Parakou, $\mathrm{Tc}=$ Tchaourou, II = agroecological Zone II, III = agroecological zone III, IV = agroecological zone IV, Ch1 = one-syllable song, Ch2 = two-syllable song, Ch3 = three-syllable song, Ch4 = four-syllable song). 


\subsection{Effect of Morphological Characters on the Number of Syllables in a Song of the Yellow-Fronted Canary}

The estimated parameters of the global logistic regression model (Table 4) showed that all the variables were insignificant in the model $(|z|<1.96, p>0.05)$. This further justifies the use of a selection procedure. Thus, in order to identify significant variables in the model, the selection procedures used have shown that the best models are those obtained with the AIC selection criterion. In fact, these models have the lowest AIC values $(63.35,63.48,63.35$, and 63.48, respectively for the four procedures Backward/Forward, Forward/backward, Backward, and Forward). The AIC values obtained with the Backward/Forward and Backward procedures are lower among these models. In addition, most of the models selected still show insignificant variables $(|z|<1.96, p>0.05)$. The elimination of these insignificant variables allowed to obtain the final model containing only the significant variables (index of beak shape, abdomen length, and tail length). However, the final model has an AIC value (AIC $=69.25$ ) slightly higher than those obtained on the models selected with the BIC criteria (AIC $=68.36$ ). These latter models also selected three variables (beak length, abdomen length, and tail length). The two models can be regarded as identical insofar as it is practically the same variables which were selected (the variable index of form of the beak is correlated with the variable beak length and the selection of one or the other is linked to random selection).

The positive values of the regression coefficients for the beak shape index $(\beta=0.80)$, the abdomen length $(\beta=19.57)$, and tail length $(\beta=9.60)$ indicated that, everything else being equal, the natural logarithm of the probability $\pi /(1-\pi)$ increases by $0.80,19.57$, and 9.60, respectively, for each additional unit of the index of beak shape, abdomen length, and tail length. Thus, for the index of beak shape, increasing this index by one unit implies that the probability $\pi$ that a bird has several sexy syllables in its song is $\exp (0.80)=2.24$ times the probability $(1-\pi)$ that the yellow-fronted canary has a sexy syllable in its song. Otherwise, an increase of one unit of this index in a bird causes that bird to be 2.24 times more likely to have several sexy syllables in its song than to have a single sexy syllable. Likewise, for the abdomen length, increasing this length by one centimeter causes the probability $\pi$ that a bird has several sexy syllables in its song is equal to $\exp (19.57)=315,604,372.06$ times the probability $(1-\pi)$ that the yellow-fronted canary has a sexy syllable in its song. Finally, for tail length, the probability $\pi$ is equal to $\exp (9.60)=14,764.78$ times the probability $(1-\pi)$. 


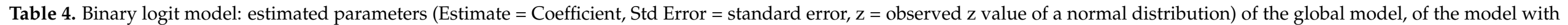
backward/forward selection, and of the model with forward/backward selection.

\begin{tabular}{|c|c|c|c|c|c|c|c|c|c|c|c|c|c|c|c|c|}
\hline \multirow{2}{*}{ Variables } & \multicolumn{4}{|c|}{ Global Model } & \multicolumn{8}{|c|}{ Variables Selected } & \multicolumn{4}{|c|}{ Final Model } \\
\hline & 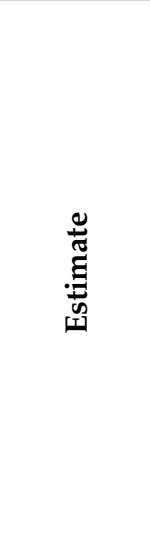 & 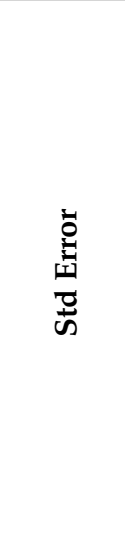 & $\mathbf{N}$ & 2 & 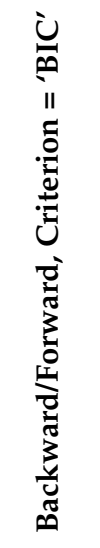 & 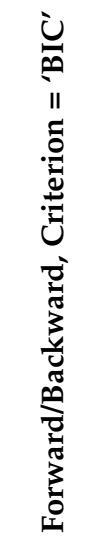 & 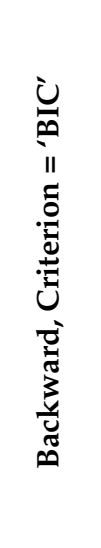 & 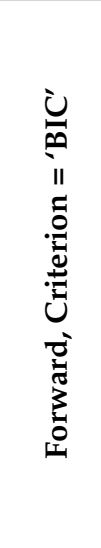 & 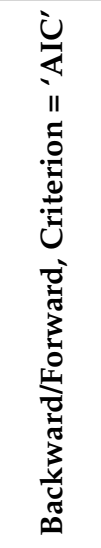 & 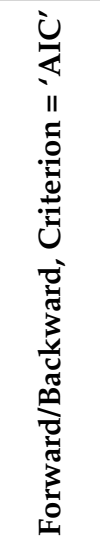 & 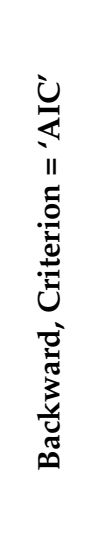 & 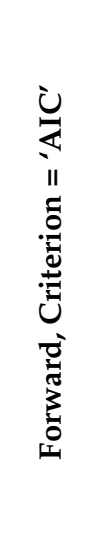 & 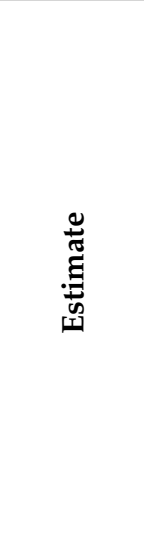 & 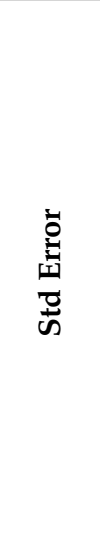 & $N$ & 2 \\
\hline Intercept & -1064.93 & 973.59 & -1.09 & 0.27 & & & & & & & & & -121.37 & 23.88 & -5.08 & $3.74 \times 10^{7}$ \\
\hline Weight & -1.07 & 0.67 & -1.61 & 0.11 & & & & & $x$ & $\mathrm{x}$ & $x$ & $x$ & & & & \\
\hline LongTo & 3.76 & 5.63 & 0.67 & 0.50 & & & & & & & & & & & & \\
\hline LongBe & -11.02 & 6.92 & -1.59 & 0.11 & $x$ & $x$ & $x$ & $x$ & $x$ & $x$ & $x$ & $x$ & & & & \\
\hline IFB & 4.46 & 11.01 & 0.41 & 0.69 & & & & & $x$ & & $x$ & & 0.81 & 0.40 & 2.00 & 0.045 \\
\hline LongTe & 4.07 & 6.88 & 0.59 & 0.55 & & & & & & & & & & & & \\
\hline LargTe & 1.01 & 4.97 & 0.20 & 0.84 & & & & & & & & & & & & \\
\hline LongPo & -0.92 & 4.42 & -0.21 & 0.84 & & & & & & & & & & & & \\
\hline Long $\mathrm{Ab}$ & 16.93 & 10.04 & 1.69 & 0.09 & $\mathrm{x}$ & $\mathrm{x}$ & $\mathrm{x}$ & $\mathrm{x}$ & $x$ & $\mathrm{x}$ & $x$ & $\mathrm{x}$ & 19.57 & 4.67 & 4.19 & 0.00003 \\
\hline LargAb & 1.95 & 9.74 & 0.20 & 0.84 & & & & & & $x$ & & $x$ & & & & \\
\hline LongCu & 12.81 & 13.09 & 0.98 & 0.33 & & & & & $x$ & & $x$ & & & & & \\
\hline LongQu & 7.77 & 5.21 & 1.49 & 0.14 & $x$ & $x$ & $x$ & $x$ & $x$ & & $x$ & $x$ & 9.60 & 3.01 & 3.19 & 0.001 \\
\hline LongTa & -481.56 & 482.95 & -1.00 & 0.32 & & & & & & & & & & & & \\
\hline LongRT & 4005.70 & 4039.64 & 0.99 & 0.32 & & & & & & & & & & & & \\
\hline LongAi & 103.27 & 106.75 & 0.97 & 0.33 & & & & & & & & & & & & \\
\hline LongAV & 0.09 & 0.63 & 0.14 & 0.89 & & & & & & & & & & & & \\
\hline Residual deviance & & 44. & & & 60.36 & 60.36 & 60.36 & 60.36 & 49.35 & 49.48 & 49.35 & 49.48 & & & & \\
\hline AIC & & 78. & & & 68.36 & 68.36 & 68.36 & 68.36 & 63.35 & 63.48 & 63.35 & 63.48 & & & & \\
\hline
\end{tabular}




\section{Discussion}

The effect of environmental conditions on changing the morphology of oscines has been discussed in the literature, particularly on Darwin's finches that Darwin used to construct his view of evolution by natural selection [23,25-28,50-55]. One major finding of the Grants' research program is that beaks evolve, by means of natural selection, in precise correspondence to changing ecological conditions, including food availability and interspecific competition. Changes in morphology can also affect the number of syllables in a song, although it can be assumed that this number of syllables is genetic or the result of sexual selection by females. Indeed, Podos and Nowicki [25] have shown that as a consequence of beak evolution, there have been changes in the structure of finch vocal signals, because beaks play a functional role in song production in songbirds. The particularity of the present work was to highlight the body parts of the animal likely to influence the number of syllables in the song. The results confirmed the effect of environmental conditions on the morphological development and implicitly on the number of syllables present in the song of the birds of yellow-fronted canary sampled.

Globally, the values noted for the morphometric characters were higher in the zones with extreme temperature of the Sudanese type (Zone II). This increase seems to follow Bergmann's ecological law, which states that the size of individuals within the same species tends to decrease as they move from the colder latitudes of their range to the hottest latitudes. These results are consistent with those of Dao [56], who showed that poultry located in dry areas have a larger wingspan than those located on the coast, where the climate is more humid. Similarly, Assefa and Melesse [57] indicated that the variation in morphometric parameters observed in poultry would be due to the availability of food and also to the climate of the environment (cold againts hot). Boudjenah [58] researched the cause of the variation of the morphometric parameters in his study on the house sparrow (Passer domesticus). In relation to these results, Lerch et al. [59] believed that during evolution, males have developed certain morphological or behavioral traits involved in reproduction, and allow individuals to evaluate and fight each other, to choose or attract a sexual partner. They went further in their analysis, stating that the evolution of morphological characters and increasingly complex vocal production are closely linked.

Moreover, according to Rehsteiner et al. [60], the preferences of females for certain types of song characteristics are linked to the qualities of the male. Similarly, only males in good conditions can produce the most complex songs in species, such as the nightingale (Luscinia megarhynchos) [61] and the swamp sparrow (Melospiza georgiana) [62]. Contrarily however, Chayet [63] reported that the evolution of individuals of the same species has a smaller conformation in the warmer areas of their range when it comes to migratory birds.

The high values of beak lengths and the relative tarsus length observed in the yellowfronted canaries of agroecological zone IV (savannah climate with a dry winter) could be explained by the presence of gallery forest along the river of Afon and Djougou classified forest (Bouloum classified forest), which give to the canaries a diet based on the leaves from different plant formations. In fact, according to Martin and Mazurek [45], the increase in the relative length of the tarsus may be related to the increasingly exclusive use of deciduous evergreen forests. Boudjenah [58] explained the observed variation in beak length by the heterogeneity of the diet between food of animal origin and food of vegetable origin. Additionally, Dietzen et al. [64], in their study on the closely related island canary, found evidence that emerging differences in beak size reflect the different dietary requirements of the bird.

The high values of the index of beak shape observed in canaries of agroecological zone II, implicitly among yellow-fronted canaries having a song consisting of several sexy syllables (found mainly in this zone), would be due to not only a much more diversified diet (insects, seeds, fruits, etc.), but also environmental conditions, because outside of the climate, there is also a stream (Alibori river) which crosses the area. Wei et al. [65] have 
shown, by studying the cettiidae, that the length and frequency of song are correlated with altitude.

The effect of morphometric parameters on the number of sexy syllables in a song showed that the index of beak shape, abdomen length, and tail length are the determining characteristics of the number of sexy syllables in a song. The coefficients of these parameters are all positive signs, so yellow-fronted canaries that have a song consisting of more than one sexy syllable are generally more likely to have not only the highest values of the index of beak shape and tail length, but also well-developed abdomen. The importance of these morphological parameters could be explained by the fact that the beak and the abdomen are especially called upon in the process of producing the complex song formed by several sexy syllables. In addition, the abdomen is involved in the coordination of inhalation and exhalation exercises during air recharging sequences during vocal production. These results are consistent with those of Podos [23], who, studying Darwin's finches from the Galapagos Islands, may have found that beak morphology and body size shape patterns of vocal signal evolution, such as birds with large beaks which develop songs with a low repetition rate of sexy syllables and small birds which repeat a high number of syllables. The author, therefore, supports the hypothesis that the morphology of the beak constrains a bird's ability to modulate songs during its creation, which largely explains the number of sexy syllables noticed in birds of the Kandi and Bouca region (ZEA II). This is what Suthers et al. [46] explained by saying that the abdominal muscles are one of the determinants of the production of so-called "sexy" syllables in yellow-fronted canaries. For Plummer and Goller [66], the vocal amplitude of a particular song element is determined by the air pressure in a bird's air sacs, which is built up by the abdominal expiratory muscles. As the size of these muscles is limited by the size of the bird's body, it follows that vocal amplitude could be an honest signal of body size [34]. Vallet [67] believes that it is different constraints at different peripheral levels that have generated anatomical and neurobiological adaptations for the production and reception of song.

The effect of tail length on the number of syllables can be explained by the fact that the size (total length) of the bird has an effect on the number of sexy syllables. Indeed, the birds of ZAE II with a large wingspan (length of the wings in flight) and a large size (total length) have a high number of sexy syllables, while birds of other areas of relatively small size have a single sexy syllable. Since the total length is strongly correlated with the length of the tail (correlation coefficient $=0.84$, Figure 3 ), the latter is implicitly also a measure of the size of the bird and, therefore, it will have an influence on the number of syllables uttered in a song.

The results obtained in this study showed the effect of the environment and the morphological characters of the yellow-fronted canary on the number of sexy syllables emitted in its song.

\section{Conclusions}

This study, which aimed to examine the effect of yellow-fronted canary morphology on the number of sexy syllables contained in a song, showed that yellow-fronted canary exhibits morphometric and acoustic diversity. Serinus mozambicus from the Sudanese climatic zone are the most developed, thus allowing them to have a plurality of sexy syllables in their song. Beak shape, abdomen length, and tail length are the characteristics that determine the number of sexy syllables in a song. These body parameters should be taken into account in any breeding and conservation program.

Author Contributions: A.H.G.A. carried out the work, collected the data, and wrote the manuscript. A.E.A. participated in the data collection. A.Y.J.A. corrected the protocol, checked the data collection forms, supervised the processing and analysis of the results, approved the method adopted, and corrected the manuscript. All authors have read and agreed to the published version of the manuscript.

Funding: This research received no external funding.

Institutional Review Board Statement: Not applicable. 
Informed Consent Statement: Not applicable.

Data Availability Statement: Not applicable.

Conflicts of Interest: The authors declare no conflict of interest.

\section{References}

1. Hausberger, M. L'apprentissage du chant chez les oiseaux: L'importance des influences sociales. In Parole et Musique Aux Origines du Dialogue Humain; Odile Jacob: Paris, France, 2008; pp. 235-251.

2. Bi, T.M.K.; Yaokokore-Beibro, H.K.; Konan, E.M.; Odoukpe, S.G.K.; Kouassi, K.P. Oiseaux comme outils d'initiation à la connaissance de la faune et du développement de la personnalité chez les Gouro de la Marahoué, centre ouest de la Cote d'Ivoire. J. Appl. Biosc. 2015, 89, 8337-8347.

3. Lougbegnon, O.T.; Codjia, J.T.C.; Liboi, M.R. Biodiversité et distribution écologique de l'avifaune des plantations du Sud du Bénin. In Actes du 1er Colloque de l'UAC des Sciences Cultures et Technologies, Agronomie; Cotonou: Cotonou, Benin, 2007 ; pp. 47-67.

4. Liu, J.P.; Ma, L.K.; Zhang, Z.Q.; Gu, D.H.; Wang, J.J.; Li, J.J.; Gao, L.J.; Hou, J.H. Aximum frequency of songs reflects body size among male dusky warblers Phylloscopus fuscatus (Passeriformes: Phylloscopidae). Eur. Zool. J. 2017, 84, 186-192. [CrossRef]

5. Catchpole, C.K.; Slater, P.J.B. Bird Song: Biological Themes and Variations; Cambridge University Press: Cambridge, UK, 2008.

6. Markowitz, J.E.; Ivie, E.; Kligler, L.; Timothy, J. Long-range Order in Canary Song. PLoS Comput. Biol. 2013, 9, e1003052. [CrossRef]

7. Cynx, J. Experimental determination of a unit of song production in the zebra finch (Taeniopygia guttata). J. Comp. Psychol. 1990, 104, 3-10. [CrossRef]

8. Aubin, T.; Rybak, F.; Courvoisier, H. Le chant des oiseaux: Un mode de communication sophistiqué. Acou. Tech. 2010, 61, 12-15.

9. Cazala, A. Codage Neuronal de L'ordre des Signaux Acoustiques Dans les Chants des Oiseaux. Doctoral Dissertation, Université Paris Saclay, Gif-sur-Yvette, France, 2019.

10. Suthers, R.A.; Vallet, E.; Kreutzer, M. Bilateral coordination and the motor basis of female preference for sexual signals in canary song. J. Exp. Biol. 2012, 215, 2950-2959.

11. Vallet, E. Communication Inter-Sexuelle Chez un Modèle D'oiseau Chanteur: Le Canari. Doctoral Dissertation, Université Paris Nanterre, Nanterre, France, 1998.

12. Kreutzer, M.; Vallet, E.; Nagle, L. Female canaries display to songs of early isolated males. Experientia 1996, 52, 277-280. [CrossRef]

13. Amy, M.; Salvin, P.; Naguib, M.; Leboucher, G. Female signalling to male song in the domestic canary (Serinus canaria). R. Soc. Open Sci. 2015, 2, 140-196. [CrossRef] [PubMed]

14. Monbureau, M.; Barker, J.M.; Leboucher, G.; Balthazart, J. Male song quality modulates c-Fos expression in the auditory forebrain of the female canary. Physiol. Behav. 2015, 147, 7-15. [CrossRef] [PubMed]

15. Pasteau, M.; Nagle, L.; Kreutzer, M. Preferences and predispositions for intra-syllabic diversity in female canaries (Serinus canaria). Behaviour 2004, 5, 571-583.

16. Garcia-Fernandez, V. Qualité du Partenaire et Qualité de L'œuf Chez les Oiseaux. Ph.D. Thesis, Université Paris Ouest La Défense, Nanterre, France, 2009.

17. Bortolotti, G.R.; Blas, J.; Negro, J.J.; Tella, J.L. A complex plumage pattern as an honest social signal. Anim. Behav. 2006, 72, 423-430. [CrossRef]

18. Soma, M.; Takahasi, M.; Hasegawa, T.; Okanoya, K. Trade-off s and correlations among multiple song features in the Bengalese finch. Ornithol. Sci. 2016, 5, 77-84. [CrossRef]

19. Spencer, K.A.; Buchanan, K.L.; Goldsmith, A.R.; Catchpole, C.K. Song as an honest signal of developmental stress in the zebra finch (Taeniopygia guttata). Horm. Behav. 2003, 44, 132-139. [CrossRef]

20. Nowicki, S.; Searcy, W.A.; Peters, S. Brain development, song learning and mate choice in birds: A review and experimental test of the "nutritional stress hypothesis". J. Comp. Physiol. A 2002, 188, 1003-1014.

21. Schmidt, K.L.; Moore, S.D.; MacDougall-Shackleton, E.A.; MacDougall-Shackleton, S.A. Early-life stress affects song complexity, song learning and volume of the brain nucleus RA in adult male song sparrows. Anim. Behav. 2013, 86, 25-35. [CrossRef]

22. Buchanan, K.L.; Spencer, K.A.; Goldsmith, A.R.; Catchpole, C.K. Song as an honest signal of past developmental stress in the European starling (Sturnus vulgaris). Proc. R. Soc. Lond. Ser. B Biol. Sci. 2003, 270, 1149-1156. [CrossRef]

23. Podos, J. Correlated evolution of morphology and vocal signal structure in Darwin's finches. Nature 2001, 409, 185-188. [CrossRef] [PubMed]

24. Danchin, E.; Giraldeau, L.-A.; Cézilly, F. Ecologie Comportementale: Cours et Question de Réflexion; Dunod, Collection Sciences Sup: Paris, France, 2005.

25. Podos, J.; Nowicki, S. Performance limits on birdsong. In Nature's Music: The Science of Birdsong; Marler, P., Slabbekoorn, H., Eds.; Elsevier/Academic: Amsterdam, The Netherlands, 2004; pp. 318-342.

26. Ota, N.; Soma, M. Age-dependent song changes in a closed-ended vocal learner: Elevation of song performance after song crystallization. J. Avian Biol. 2014, 45, 566-573. [CrossRef]

27. Hall, M.L.; Kingma, S.A.; Peters, A. Male songbird indicates body size with low-pitched advertising songs. PLoS ONE 2013, 8, e56717. [CrossRef]

28. Price, J.J.; Crawford, C.L. Use and characteristics of two singing modes in Pine Warblers. Wilson J. Ornith. 2013, 125, 552-561. [CrossRef] 
29. Holveck, M.-J.; Riebel, K. Preferred songs predict preferred males: Consistency and repeatability of zebra finch females across three test contexts. Anim. Behav. 2007, 74, 297-309. [CrossRef]

30. Soma, M.; Garamszegi, L.Z. Rethinking birdsong evolution: Meta-analysis of the relationship between song complexity and reproductive success. Behav. Ecol. 2011, 22, 363-371. [CrossRef]

31. Hesler, N.; Mundry, R.; Sacher, T.; Coppack, T.; Bairlein, F.; Dabelsteen, T. Song repertoire size correlates with measures of body size in Eurasian blackbirds. Behaviour 2012, 149, 645-665. [CrossRef]

32. Kagawa, H.; Soma, M. Song performance and elaboration as potential indicators of male quality in Java sparrows. Behav. Process. 2013, 99, 138-144. [CrossRef]

33. Poesel, A.; Kunc, H.P.; Foerster, K.; Johnsen, A.; Kempenaers, B. Early birds are sexy: Male age, dawn song and extrapair paternity in blue tits, Cyanistes (formerly Parus) caeruleus. Anim. Behav. 2006, 72, 531-538. [CrossRef]

34. Brumm, H. Song amplitude and body size in birds. Behav. Ecol. Sociobiol. 2009, 63, 1157-1165. [CrossRef]

35. Schuchmann, M.; Siemers, B.M. Variability in echolocation call intensity in a community of horseshoe bats: A role for resource partitioning or communication? PLoS ONE 2010, 5, e12842. [CrossRef] [PubMed]

36. Ryan, M.J.; Brenowitz, E.A. The role of body size, phylogeny, and ambient noise in the evolution of bird song. Am. Nat. 1985, 126, 87-100. [CrossRef]

37. Tubaro, P.L.; Mahler, B. Acoustic frequencies and body mass in New World doves. Condor 1998, 100, 54-61. [CrossRef]

38. Laiolo, P.; Rolando, A.; Delestrade, A.; De Sanctis, A. Vocalizations and morphology: Interpreting the divergence among populations of Chough Pyrrhocorax pyrrhocorax and Alpine Chough P. graculus. Bird Study 2004, 51, 248-255. [CrossRef]

39. Koetz, A.H.; Westcott, D.A.; Congdon, B.C. Geographical variation in song frequency and structure: The effects of vicariant isolation, habitat type and body size. Anim. Behav. 2007, 74, 1573-1583. [CrossRef]

40. Potvin, D.A. Larger body size on islands affects silvereye Zosterops lateralis song and call frequency. J. Avian Biol. 2013, 44, 221-225. [CrossRef]

41. Linhart, P.; Fuchs, R. Song pitch indicates body size and correlates with males response to playback in a songbird. Anim. Behav. 2015, 103, 91-98. [CrossRef]

42. Mason, N.A.; Burns, K.J. The effect of habitat and body size on the evolution of vocal displays in Thraupidae (tanagers), the largest family of songbirds. Biol. J. Linn. Soc. 2015, 114, 538-551. [CrossRef]

43. Geberzahn, N.; Goymann, W.; Muck, C.; Cate, C.T. Females alter their song when challenged in a sex-role reversed bird species. Behav. Ecol. Sociobiol. 2009, 64, 193-204. [CrossRef]

44. Miyashita, A.; Kizaki, H.; Sekimizu, K.; Kaito, C. No effect of body size on the frequency of calling and courtship song in the two-spotted Cricket, Gryllus bimaculatus. PLoS ONE 2016, 11, e0146999. [CrossRef]

45. Martin, J.-L.; Mazurek, H. Etude des variations géographiques de la morphologie d'un passereau, Parus caeruleus. Mappemonde Montp. 1986, 3, 22-25. Available online: www.mgm.fr/PUB/Mappemonde/M386/p22-25.pdf (accessed on 12 June 2021).

46. Suthers, R.A.; Margoliash, D. Motor control of birdsong. Curr. Opin. Neurobiol. 2002, 12, 684-690. [CrossRef]

47. R Core Team. R: A Language and Environment for Statistical Computing; R Foundation for Statistical Computing: Vienna, Austria, 2020; p. 201. Available online: www.R-project.org/ (accessed on 13 February 2021).

48. Gideon, S. Estimating the dimension of a model. Ann. Stat. 1978, 6, 461-464.

49. Akaike, H. Information theory and an extension of the maximum likelihood principle. In Second International Symposium on Information Theory; Akademiai Kiado: Budapest, Hungary, 1973; pp. 267-281.

50. Grant, P.R.; Grant, B.R. Predicting microevolutionary responses to directional selection on heritable variation. Evolution 1995, 49, 241-251. [CrossRef]

51. Grant, P.R.; Grant, B.R. Adaptive radiation of Darwin's finches. Am. Sci. 2002, 90, 130-139. [CrossRef]

52. Grant, P.R. Ecology and Evolution of Darwin's Finches; Princeton University Press: Princeton, NJ, USA, 1999.

53. Schluter, D.; Price, T.D.; Grant, P.R. Ecological character displacement in Darwins finches. Science 1985, 227, 1056-1059. [CrossRef]

54. Bowman, R.I. Morphological differentiation and adaptation in the Galápagos finches. Univ. Calif. Publ. Zool. 1961, 58, 1-302.

55. Lack, D. Darwin's Finches; Cambridge University Press: Cambridge, UK, 1947.

56. Dao, B. Caractérisation Phénotypique et Moléculaire des Populations Locales de poules du Togo; Rapport Technique; ITRA/MAEH: Lomé, Togo, 2015.

57. Assefa, H.; Melesse, A. Morphological and morphometric characterization of indigenous chicken populations in Sheka Zone, South Western Ethiopia. Poult. Fish. Wildl. Sci. 2018, 6, 2. [CrossRef]

58. Boudjenah, S. Etude des hémoparasites des oiseaux dans la région de Guelma: Cas du Moineau domestique Passer domesticus. Master's Thesis, Université 8 Mai 1945, Guelma, Algeria, 2015.

59. Lerch, A.; Nagle, L. Chants et préférences sexuelles chez les oiseaux chanteurs. Acous. Tech. 2010, 61, 16-19.

60. Rehsteiner, U.; Geisser, H.; Reyer, H.U. Singing and mating success in water pipits: One specific song element makes all the difference. Anim. Behav. 1998, 55, 1471-1481. [CrossRef]

61. Kipper, S.; Kiefer, S.; Bartsch, C.; Weiss, M. Female calling? Song responses to conspecific call playbacks in nightingales, Luscinia megarhynchos. Anim. Behav. 2015, 100, 60-66. [CrossRef]

62. Ballentine, B. The ability to perform physically challenging songs predicts age and size in male swamp sparrows, Melospiza georgiana. Anim. Behav. 2009, 77, 973-978. [CrossRef] 
63. Chayet, D. Des oiseaux migrateurs rétrécissent pour s'adapter au changement climatique. Ecol. Lett. 2019. Available online: www.lefigaro.fr/sciences/des-oiseaux-migrateurs-retrecissent-pour-s-adapter-au-changement-climatique-20191206 (accessed on 22 April 2021)

64. Dietzen, C.; Voigt, C.; Gahr, M.W.M.; Leitner, S. Phylogeography of island canary (Serinus canaria) populations. J. Ornithol. 2006, 147, 485-494. [CrossRef]

65. Wei, C.; Price, T.D.; Liu, J.; Alström, P.; Zhang, Y. The evolutionary origin of variation in song length and frequency in the avian family Cettiidae. J. Avian Biol. 2017, 48, 1295-1300. [CrossRef]

66. Plummer, E.M.; Goller, F. Singing with reduced air sac volume causes uniform decrease in airflow and sound amplitude in the zebra finch. J. Exp. Biol. 2008, 211, 66-78. [CrossRef] [PubMed]

67. Vallet, E. Séduire à Coup Sûr: Ce Que Nous Apprennent les Chants des Canaris; Université Paris Nanterre: Nanterre, France, 2016. 